\title{
Microcredit and Poverty Reduction: A Case Study of Microfinance Fund for Community Development in Northern Vietnam
}

\author{
Do Xuan Luan ${ }^{1,2}$ \\ ${ }^{1}$ Faculty of economics and rural development, Thai Nguyen University of Agriculture and Forestry, Vietnam \\ ${ }^{2}$ Institute of Project and Regional Planning, Justus-Liebig-University, Germany \\ Correspondence: Do Xuan Luan, Institute of Project and Regional Planning, Justus-Liebig-University, \\ Senckenbergstrasse 3, D-35390 Giessen, Germany. Tel: 49-152-1160-4795. E-mail: \\ luan.x.do@agrar.uni-giessen.de; doxuanluan@gmail.com
}

Received: April 26, 2015 Accepted: June 23, 2015 Online Published: July 15, 2015

doi:10.5539/jas.v7n8p44 URL: http://dx.doi.org/10.5539/jas.v7n8p44

\begin{abstract}
Like other developing countries, microcredit in Vietnam has been recognized as an important credit source of the poor, who need capital but are normally by-passed by commercial banks. However, the provision of credit to the poor is challenged by the existing tradeoff between depth of outreach and financial sustainability. In this study, Principal Component Analysis and Propensity Score Matching were used to assess whether microcredit reaches the poor and its role in poverty reduction. The Microfinance Fund and Community Development (MFCD), a microfinance institution in Northern Vietnam was selected as a case study. The research has shown that microcredit successfully reaches the poor households as $67 \%$ of credit recipients belong to the last three bottom groups. The observed poverty targeting is consistent with the mission of the microfinance institution. In addition, the provision of microcredit has positive but statistically insignificant impact on household income and expenditure. This study suggests that unless access to additional resources should be made available to the poor, a small amount of credit alone could be insufficient to reduce poverty.
\end{abstract}

Keywords: microcredit, poverty targeting, poverty reduction, Northern Vietnam

\section{Introduction}

In developing countries, lack of access to credit is regarded as one of the most crucial reasons explaining why the poor rural households remain poor (Collins et al., 2009). Vietnam, a developing country in Southeast of Asia, is not an exceptional case. The rural areas in Vietnam are also the place, where nearly $94 \%$ of the poor live. In the country, the provision of credit to farm households is mainly implemented by two banks including the Vietnam Bank for Social Policy and the Agricultural Bank of rural development, which make up about 70\% of total rural loans outstanding. Microfinance Institutions (MFIs) have joined to increase the credit supply through microcredit schemes in the rural credit market. However, the share of loan outstanding disbursed by MFIs only represents nearly $1 \%$ of the total rural loans outstanding (Tam, 2013). The credit disbursed to rural areas in Vietnam is far limited when compared to the credit demand of rural areas and the role of rural areas in the socio-economic development of the country. As a consequence, lack of credit and other appropriate and available financial services in rural areas make the poor households in the country very vulnerable to risks (Kim Anh et al., 2011). In order to increase the provision of credit to the poor, the government has set up the national program for developing microfinance in the whole country up to the year 2020. Accordingly, a number of semi-formal MFIs are targeted to become formal credit institutions. The legal framework has been constructed to promote the development of semi-formal credit organizations. For instance, Decree 165/2007/ND-CP was introduced to regulate the criteria for a MFI to be licensed officially. Apart from creating the opportunities for MFIs to conveniently access capital from donors, the decree also creates the pressure for MFIs to fulfill the requirement of financial sustainability. Under financial pressure, MFIs could shift their focus to lending the wealthier households, which are believed to have better abilities to repay. In other words, the development of rural credit may lead to a situation in that the poor households might be excluded from accessing financial services like microcredit. In order to design credit schemes for poor households, it is very essential to identify the level of serving the poor. It is also necessary to know how credit affects household welfare. Obviously, the continuous provision of microcredit to the poor depends very much on the household benefits from using loans. For these 
reasons, this study aims to achieve two main objectives: (1) To analyze the extent to which microcredit serves the poor households; (2) To estimate and assess the welfare impact of microcredit on accessed households.

\section{Data and Method}

\subsection{Data}

Data used in this study is taken from the household survey carried out in 2012. To eliminate the issue of self-selection bias, both clients and non-clients in the same villages were surveyed. As shown in Table 1, the total 177 surveyed households are from two districts including Soc Son and Lac Son in the Northern Vietnam. Lac Son is a mountainous and disadvantaged district of Hoa Binh province. It is amongst the poorest districts in the country, with $47 \%$ of households living below the national rural poverty line in 2012. As of 2012, it had a population of 134,132 , of which $98.51 \%$ of population lived in rural areas and engaged in farming activities (General Statistics Office of Vietnam, 2012). Soc Son is one of the poorest districts of Hanoi, the capital city of Vietnam. These two districts are interesting cases because they are located in different altitudes and obtain different market access conditions to the capital of Ha Noi. Lac Son is located about 111 kilometers, while Soc Son is 32 kilometers far from the center of Hanoi capital. Soc Son has better socio-economic development compared to Lac Son. Both districts have the presence of microcredit served by the Microfinance Fund and Community Development (MFCD).

Table 1. Composition of selected households categorized by locations and credit sources

\begin{tabular}{|c|c|c|c|c|c|c|}
\hline \multirow{2}{*}{ Districts } & \multicolumn{2}{|c|}{ Without credit } & \multicolumn{2}{|c|}{ With credit } & \multicolumn{2}{|c|}{ Total } \\
\hline & Frequency & $\%$ & Frequency & $\%$ & Frequency & $\%$ \\
\hline Soc Son & 62 & 35.03 & 37 & 20.90 & 99 & 55.93 \\
\hline Lac Son & 54 & 30.51 & 24 & 13.56 & 78 & 44.07 \\
\hline Total & 116 & 65.54 & 61 & 34.46 & 177 & 100 \\
\hline
\end{tabular}

Source: Own data.

In the sampled households, $34.46 \%$ borrowed from MFCD and the rest of them did not acquire any loans in the previous 12 months. Each credit-accessed household receives an equal amount of 5 VND millions and pays a monthly interest rate of $1 \%$. The maturity duration of a loan is within 12 months from inception. MFCD, a semi-formal institution, was established and has operated since 2007. Its social mission statement is "improving quality of life and social status of poor households, poor and vulnerable groups in society and their families through the provision of financial services and effective and sustainable non-financial services". Up to 2012, the organization has disbursed over six VND billions to more than 6000 farm households in four provinces including Ha Noi, Hoa Binh, Nghe An and Quang Binh province in Vietnam (MFCD, 2012). Loans of MFCD are normally disbursed monthly in the group meetings, where staffs of MFCD also receive application forms and collect repayment. The lending schedule is based on the seasonality of agricultural production. Loans are usually disbursed before the start of production seasons, when households need capital to purchase agricultural inputs and production equipment.

\section{2 Method}

\subsubsection{Poverty Targeting Measurement}

In order to evaluate the extent to which credit serves the poor households, this study uses the relative poverty index calculated by Principal Component Analysis (PCA). Relative poverty can reflect the long-term economic status of households and depend less on the short-term fluctuations in income and expenditure (Filmer \& Pritchett, 2001). The main idea in calculating relative poverty is to reduce the dimensionality of the poverty dataset (Henry, 2003). The use of the first component, which accounts for a highest eigenvalue of the correlation matrix, is plausible (Abdi \& Williams, 2010). The first component is computed by a linear combination of variables, which best describe poverty situation of households as follows:

$$
\mathrm{P}_{\mathrm{i}}=\mathrm{w}_{1} \mathrm{X}_{1}+\mathrm{w}_{2} \mathrm{X}_{2}+\ldots+\mathrm{w}_{\mathrm{n}} \mathrm{X}_{\mathrm{n}}
$$

Where,

$\mathrm{w}_{1}, \mathrm{w}_{2}, \mathrm{w}_{3} \ldots \mathrm{w}_{\mathrm{n}}$ are the weights specified such that the poverty score index accounts for the maximum variances in $X_{1}, X_{2, \ldots} X_{n}$, which are standardized variables. The analysis is then equivalent to the calculation of the first component from the original variables after these have been standardized. Because the original variables have 
very different measurements, they need to be standardized as follows:

$$
X_{n}=\frac{x_{n}-\mu_{n}}{S_{n}}
$$

Where,

$\mathrm{x}_{\mathrm{n}}$ is the value of the variable of households in dataset, $\mu_{\mathrm{n}}$ and $\mathrm{S}_{\mathrm{n}}$ are the mean and standard deviation of the variable for the whole dataset. Standardized variables have a mean of zero and a standard deviation of one. A household, which has a lower score, is relatively poorer.

Theoretically, variables which might be associated with the poverty status, are selected on the basis of the poverty characteristics of the research areas, the literature review and expert consultation. Furthermore, the final variables used in the Principal Component Analysis are chosen based on the statistical analysis. Accordingly, the criteria for variable selection rely on the strength and significance of the correlation of each variable with the poverty benchmark indicator. Only those statistically correlated with the significance level of less than one percent with the benchmark indicator are used in the Principal Component Analysis. Using a Pearson's $r$ to calculate the correlation between a binary variable and a continuous variable results in an inflated coefficient and leads the researcher to a false conclusion (Becketti, 1994). The point biserial correlation is therefore a preferred statistical procedure for calculating a simple correlation coefficient between a continuous variable and a dichotomous variable. The point biserial correlation $\left(r_{b p}\right)$ is the value of Pearson's product moment correlation when one of the variables is dichotomous and the other variable is metric (Kornbrot, 2005). The correlation is computed based on the following formula:

Where,

$$
r_{p b}=\frac{\bar{Y}_{1}-\bar{Y}_{0}}{\bar{s}_{y}} \sqrt{\frac{N_{1} N_{0}}{N(N-1)}}
$$

$\bar{Y}_{1}$ and $\bar{Y}_{0}$ are means of the continuous variables coded 0 and 1 respectively;

$N_{0}$ and $N_{1}$ are number of observations coded 0 and 1 respectively;

$N$ is total number of observation $N_{0}+N_{1}$;

$\bar{s}_{y}$ is the standard deviation of all the metric observations.

After computing relative poverty scores, non-accessed farm households are first categorized in different groups including the poorest, the less poor, the medium, the better off and the wealthiest. The credit non-accessed households, representing the general households, are used as the reference groups. The interpretation of the poverty targeting in the poorest group is illustrated as an example. If the proportion of accessed households in this group equals $20 \%$, then the proportion of the poorest households among borrowers is the same as in the general population. A proportion greater than $20 \%$ means the poverty target is deeper in this group. A proportion less than $20 \%$ implies that the poor borrowers in this group are underserved by microcredit.

\subsubsection{Impact Estimation}

In order to estimate the impact of credit, this study uses the approach of Propensity Score Matching (PSM) instead of using normal regressions. Imbens and Rubin (2015) showed that using simple regression methods to estimate the impact will not necessarily be adequate for removing the biased associated with the differences in covariates. Also, regressions are much more sensitive to functional forms compared to PSM (Blundell \& Dias, 2009). PSM gives less biased estimation results compared to Ordinary Least Square estimation because it compares the outcomes between household groups with similar characteristics (Huber et al., 2013). Especially, PSM is able to deal with the problem of sample selection bias, a common issue of rural credit studies occurring due to some unobservable variables not taken into the credit access model but also influence the household outcome. More importantly, using PSM is much more flexible to estimate the welfare impact of credit on multiple outcome variables of interest (Caliendo \& Kopeinig, 2008). PSM is estimated through two steps as follow:

The first step is to analyze the factors affecting to the household decision to take credit. Specifically, this procedure is similar to the estimation of a probit model, which is shown in the following equation:

$$
L_{i}=\beta X_{i}+\varepsilon_{i}
$$

Where:

$L_{i}$ : is a latent variable, which is not observed. $L_{i}$ could be the difference between the benefits and costs of taking a loan. If the difference is positive, then the household chooses to take a loan. However, only the indicator for 
taking a loan is observed and defined as:

$T_{i}=1$ if $L_{i}>0$ : the household took a loan;

$T_{i}=0$ otherwise: the household did not take a loan;

$X_{i}$ is a vector of exogenous household characteristics that influence to $L_{i}$.

Because $T_{i}$ is a binary dependent variable, the application of the Ordinary Least Square (OLS) method suffer some problems. Specifically, the heteroscedastic errors are a function of the parameter vector $\beta$. In addition, the predicted values can take values outside the interval of between 0 and 1 (Tektas \& Gunay, 2008). Therefore, the maximum likelihood estimation is more appropriate in this case (Bun, 2002).

The second step of PSM is to compare the differences in means of outcome variables between non-accessed households and accessed ones. Both groups have similar characteristics except for credit access. The welfare impact denoted by the Average Treatment Effects on the Treated (ATT) and expressed formally as:

$$
\mathrm{ATT}=\mathrm{E}(\Delta \mid \mathrm{D}=1)=\mathrm{E}\left(Y^{1} \mid D=1\right)-\mathrm{E}\left(Y^{0} \mid D=0\right)
$$

Where,

$\mathrm{E}\left(\mathrm{Y}^{1} / \mathrm{D}=1\right)$ represents the outcome of recipients;

$\mathrm{E}\left(\mathrm{Y}^{0} / \mathrm{D}=0\right)$ represents the outcome of non-recipients.

In this study, the approach of Nearest Neighbor Matching is selected as a matching algorithm due to the different distribution in the propensity score between two groups. In addition, the matching with replacement is employed due to the higher quality of matching and the smaller bias (Imbens \& Rubin, 2015). In order to make the estimation results less sensitive to infer to the larger population, the bootstrapping technique is further used for PSM (Austin \& Small, 2014). Accordingly, the distribution of the ATT estimator is constructed.

\section{Results}

\subsection{Poverty Targeting of Microcredit}

Table 2 reports the results of Principal Component Analysis. Results show that the first component which account for the largest proportion of total variability in the set of variables is chosen. All variables which contribute to the relative poverty index have consistent and expected signs. The table also reveals that all variables have strong correlation with per capita income. Component loading coefficients represent the amount of correlation between the variable and the first component. Most variables load quite strongly to the fist component reflecting the significant interrelationship between the first component and the remaining variables. All selected variables have positive coefficients indicating a direct relationship between the variable and the relative poverty of households. For instance, the household owning a more valuable home building is relatively wealthier as compared to other ones. Furthermore, the Kaiser-Meyer-Olkin (KMO) test is an index for comparing the magnitudes of observed correlation coefficients with the magnitudes of partial correlation coefficients. The smaller the value of the index, the less appropriate the model. In this study, the KMO equals 0.70 indicating the adequacy of the sampling. In other words, all variables used are appropriate to measure one common component. 
Table 2. Results of principal component analysis

\begin{tabular}{|c|c|c|c|c|}
\hline Variable & Mean & $\begin{array}{l}\text { Standard } \\
\text { deviation }\end{array}$ & $\begin{array}{l}\text { Correlation } \\
\text { coefficient }\end{array}$ & $\begin{array}{l}\text { Factor } \\
\text { loadings }\end{array}$ \\
\hline Income per capita (VND million) & 10.84 & 7.05 & 1 & 0.2842 \\
\hline Value of house (VND million) & 73.27 & 56.90 & $0.3737^{* * *}$ & 0.4881 \\
\hline Kind of cooker ( $1=$ gas and electric cooker $)$ & .43 & .49 & $0.1519^{* * *}$ & 0.5151 \\
\hline $\begin{array}{l}\text { Main source of water for cooking and drinking (1=tap water or } \\
\text { purchased water in tank, bottle) }\end{array}$ & .27 & .44 & $0.1741^{* * *}$ & 0.3405 \\
\hline $\begin{array}{l}\text { Type of toilet arrangement }(1=\text { flush toilet with specific tank and } \\
\text { sewage pipes })\end{array}$ & .40 & .49 & $0.1376^{* * *}$ & 0.5155 \\
\hline Education level of household head (years in school) & 6.59 & 3.15 & $0.4467^{* * *}$ & 0.1845 \\
\hline \multicolumn{5}{|l|}{ Model specification } \\
\hline Eigen value & 2.41 & & & \\
\hline Variance explained (\%) & 40.25 & & & \\
\hline Kaiser-Meyer-Olkin Measure of Sampling Adequacy (KMO) & 0.70 & & & \\
\hline
\end{tabular}

Source: Own calculation.

After computing the relative poverty score for each individual household, 116 credit non-recipients representing the general population were sorted in an ascending order based on their poverty scores. Then, those households were classified into 5 equal groups. The top fifth refers to the "richest" group and the last fifth represents the "poorest" group. As a result, each group accounts for $20 \%$ of total non-recipients. Table 3 reports the cutoff scores between five groups .

Table 3. Poverty cutoff scores for credit non-accessed farm households $(\mathrm{n}=116)$

\begin{tabular}{llc}
\hline Categories & Lower bound & Upper bound \\
\hline Poorest & -2.2763 & -1.7247 \\
Less poor & -1.6919 & -1.1711 \\
Medium & -2.4502 & -0.1466 \\
Better off & 0.0281 & 1.0745 \\
Richest & 1.108 & 4.1362
\end{tabular}

Source: Own calculation.

In order to use the relative poverty scores for comparisons, the non-accessed households are first sorted in an ascending order based on their indexes. The top fifth of the non-accessed households will be grouped in the "richest group" and the bottom fifth in the "poorest group". Therefore, each quintile of the non-accessed household represents $20 \%$ of total non-recipients. The cut-off scores for each quintile determine the border or the limits between poverty groups. Credit recipients are then assigned in the five groups based on their relative poverty scores. The differences in percentages between credit recipients and non-recipients in each poverty group imply the depth of credit outreach. Figure 1 presents the outreach of microcredit, the indicator of interest. 




Figure 1. Poverty outreach of microcredit

Source: Own calculation.

Results showed that credit accessed households are overrepresented in the less poor group while underrepresented in remaining groups. Considering the medium group as the base line of relative poverty, $67 \%$ of accessed households belong to the three bottom groups. In general, the poverty targeting in this case is consistent with the explicit mission of MFCD to provide credit to the poor households. However, the poorest are still excluded to access microcredit. These results are in line with those of previous studies. The fact that credit targets the poorest has not previously been described in a number of published studies (Amin et al., 2003; Coleman, 2006; Ghalib, 2011; Li et al., 2011; Milan, 2012). Also, evidence of Dufhues and Buchenrieder (2005) indicated that the poorest are seldom clients of credit. Another study conducted by Navajas et al. (200) stated that in Bolivia the poorest households are less likely to be assessed as creditworthy or to demand loans of the type offered by the industry. This result may be explained by the fact that poorer households, especially the poorest normally have a lower level of education, limited production skills and limited access to resources.

\subsection{Welfare Impact of Microcredit}

\subsubsection{Description of Variables and Assumptions}

Access to microcredit is not random but conditional on household endowments. In this study, the choice of relevant variables is based on literature review and potential significance for policy interventions. The description and statistical test for the difference in means of selected variables between different household groups are reported in Table 2.

Age of household heads represents farming experience, which is relevant to productivity and efficiency of farming production (de Sherbinin et al., 2008). In addition, age influences the household economic decision making with regard to consumption and production (Girish \& Mehta, 2003). Age also represents the social reputation and attitude to debt, which are crucial in credit transactions. Income generated by household heads and their family increase to a peak as their career develops then declines when they get older. Hence, the age of the household head should be squared (Zeller \& Sharma, 2000).

Gender of household head is another variable of interest. Female headed households are considered to be more creditworthy because female heads tend spend a higher proportion of income on education and health care of their families (Hopkins et al., 1994). Therefore, female headed farm households are assumed have better credit access.

A household head with a higher level of education is believed to be a better manager regarding farm household decisions, performing better risk management and higher income generation (Foltz, 2004). Moreover, education level also represents the abilities of households heads to access information and to work in off-farm activities. Lenders believe that more educated households are more creditworthy than less educated ones (Khalid, 2003; Okurut, 2004). Education and training experiences of borrowers are positively associated to famer profits and their abilities to repay (Brehanu \& Fufa, 2008). 
Table 2. Descriptive statistics of selected variables used in Propensity Score Matching

\begin{tabular}{|c|c|c|c|c|c|c|}
\hline \multirow{2}{*}{ Variables } & \multicolumn{2}{|c|}{ Accessed households } & \multicolumn{2}{|c|}{ Non-accessed households } & \multicolumn{2}{|c|}{ All sample } \\
\hline & Mean & $\mathrm{Sd}$ & Mean & $\mathrm{Sd}$ & Mean & $\mathrm{Sd}$ \\
\hline Age of household head (years) ${ }^{* * *}$ & 45.72 & 11.15 & 50.89 & 14.21 & 49.11 & 13.43 \\
\hline Age of household head squared (years squared) ${ }^{* * *}$ & 2212.74 & 1007.38 & 2789.69 & 1508.42 & 2590.85 & 1381.41 \\
\hline Gender of household head $(1=\text { male })^{* * *}$ & .90 & .30 & .67 & .47 & .75 & .43 \\
\hline Educational level of household head (years in school) ${ }^{* * *}$ & 7.60 & 3.42 & 6.06 & 2.87 & 6.59 & 3.15 \\
\hline Total land size (hectare) ${ }^{* * *}$ & 4.36 & 5.23 & 2.12 & 2.19 & 2.89 & 4.07 \\
\hline Value of house (VND million) & 68.77 & 46.56 & 75.63 & 61.70 & 73.27 & 56.90 \\
\hline Location of farm household $(1=\text { Lac Son })^{*}$ & .39 & .49 & .53 & .50 & .48 & .50 \\
\hline Family size (persons) $^{* * *}$ & 4.63 & 1.71 & 3.37 & 1.32 & 3.81 & 1.58 \\
\hline Frequency of agricultural extension visits (number) & 3.99 & 2.39 & 2.48 & 2.01 & 3.00 & 2.26 \\
\hline Shock losses (VND million) & 3.16 & 2.22 & 2.85 & 2.02 & 2.83 & 2.17 \\
\hline Distance to the district center (kilometers) & 11.70 & 5.74 & 12.03 & 6.04 & 11.92 & 5.92 \\
\hline Total income & 35.78 & 13.46 & 35.44 & 14.20 & 35.56 & 13.91 \\
\hline Total expenditure & 32.71 & 11.81 & 31.62 & 12.07 & 31.99 & 11.96 \\
\hline Per capita income ${ }^{* * *}$ & 8.24 & 2.49 & 12.20 & 8.20 & 10.84 & 7.05 \\
\hline Per capita expenditure ${ }^{* * *}$ & 7.56 & 2.28 & 10.92 & 7.16 & 9.76 & 6.15 \\
\hline
\end{tabular}

Note. ${ }^{*}$ significant at $10 \% ;{ }^{* *}$ significant at $5 \% ;{ }^{* * *}$ significant at $1 \%$. Differences in means of selected variables between accessed households and non-accessed households. t-statistics are computed for continuous variables and Pearson chi2 is applied for discrete variables.

Source: Own calculation.

Land size refers to the total land area of the household. Agricultural land is a special input which represents the capacity of farm households to produce higher yield and higher income and resident land reflects the wealth level of households. It is assumed that a larger land size can improve credit accessibility by rural households.

Value of houses at local market prices is an important indicator which indicates the asset value of rural households in Vietnam. A valuable house is believed to represent the relative wealth level of households which determines credit accessibility of households (Takahashi et al., 2010). The higher value of assets improves repayment rates (Duca \& Whitesell, 1995).

The dummy variable of household location is used to control for the agro-ecological and socioeconomic conditions of both districts that might influence the repayment ability of borrowers. Households in Soc Soc district are assumed to access better socio-economic development conditions and better access to credit.

On the one hand, a larger household size might indicate a greater number of laborers, which create a potential for the household to adopt farming technologies and generate greater profits (Nuryartono et al., 2005). Larger size households tend to have a better social network increasing the probability of accessing informal credit (Yuan \& $\mathrm{Xu}, 2015)$. On the other hand, a larger household size might increase the dependency ratio creating the likelihood of using credit for consumption purposes. Consequently, households with a higher number of dependents are considered to be less able to improve their living standard and hence, less creditworthy (Bao Duong \& Izumida, 2002).

Access to agricultural extension services such as information support, input supply, and training are very essential to help famers manage and use resources more effectively (Buadi et al., 2013). At the same time, maintaining relationships with agricultural extension stations might improve the household social capital. In return, social capital is very useful to provide information about credit programs to potential borrowers and reduce their costs of searching (Okten \& Osili, 2004).

Exposure to shocks such as bad weather conditions can negatively impact farming productivity (Zeller et al., 2000). As a consequence, lending to the agricultural sector is considered to be so risky that lenders are not 
willing to participate. Access to credit is, therefore, limited for farmers (Globalagrisk, 2009). Economic losses due to agricultural shocks directly reduce income and savings and might push rural households into further poverty.

The distance of the household to the district center is used to capture household access to information, market and transaction costs as well. It is expected that a greater distance hinders household social communication and increases transaction costs, decreasing the probability of credit access and repayment (Khoi et al., 2013; Stanton, 2002).

\subsubsection{Determinants of Credit Access}

Table 3 presents the estimated results of the probit model. Wald chi-square statistic equals 73.16 leading to reject the null hypotheses that all parameters in the model are equal to zero. In other words, the model is appropriate at the confidence level of $99 \%$. The probit models predicted $81.36 \%$ of all households correctly and the Pseudo R-squared equals 0.43 . These results indicate that the goodness of fit are satisfied.

Table 3. Determinants of credit accessibility (robust estimator)

\begin{tabular}{lll}
\hline Explanatory variables & Coefficient & Z-value \\
\hline Age of household head (years) & .148 & $1.67^{*}$ \\
Age of household head squared (year squared) & -.001 & $-1.73^{*}$ \\
Gender of household head (1=male) & .382 & 1.03 \\
Educational level of household head (years in school) & .230 & $4.06^{* * *}$ \\
Land size (hectare) & .311 & $5.58^{* * *}$ \\
Value of house (VND million) & -.003 & $-1.71^{*}$ \\
Family size (persons) & .178 & $2.21^{* *}$ \\
Number of agricultural extension visits (number) & .149 & $2.42^{* *}$ \\
Shock losses (VND million) & .032 & 0.51 \\
Location of household (1=Lac Son) & -.060 & -0.24 \\
Distance to the district center (km) & .002 & 0.11 \\
Constant & -7.473 & $-3.56^{* * *}$ \\
Model specification & & \\
Observations & 177 & \\
Wald chi2 (11) & 73.16 & \\
Prob > chi2 & 0.0000 & \\
Pseudo R2 & 0.4292 & \\
Correctly classified (\%) & 81.36 & \\
\hline Dependent variable: 1 (with access), 0 (without access); significant at $10 \%{ }^{* *}$ & \\
\hline
\end{tabular}

Note. Dependent variable: 1 (with access), 0 (without access); ${ }^{*}$ significant at $10 \% ;{ }^{* *}$ significant at $5 \%$; ${ }^{* * *}$ significant at $1 \%$.

Source: Own calculation.

The coefficients of age and age squared are statistically significant at the $10 \%$ level. As expected, access to credit decreases when household heads get older. The gender of household heads has positive sign but is not significant. Microcredit tends be provided to male headed households. In most of rural areas in Vietnam, husbands are still dominant as the household heads.

The educational level of household heads has a positive and significant coefficient at the 5\% level. Education enables clients to read and understand the credit contracts, principles, and duties and responsibilities during the membership period. The credit institution seems to target the potential clients, who are literate and have higher educational levels. Educational level is believed to have positive association with income generation and household's production management. In addition, better education can help the credit institution reduce training costs for new members and introduce new innovative courses conveniently. Furthermore, better educational household heads might be more likely to access off-farm activities, which might require a certain level of skills and qualification. 
Land size is an important factor determining the credit accessibility because it not only represents one important asset but also reflects the higher demand for credits of rural households. As expected, households with a larger area of land are more likely to access credit.

The coefficient of value of house is negative and significant at the $10 \%$ level. A household which owns a more valuable house, is less likely to accessing microcredit. This could be explained by the credit policy of MFCD, which targets the poor households, which own less valuable residential buildings. Another reason could be attributed by the fact that a wealthier household might have less demand for small loans.

The coefficient of family size is positive and significant at the 5\% level. This result indicates that households with a higher family size are more likely to access microcredit. Farming production in the research areas is characterized by labor-intensive technology. Larger size households might demand more credit to take advantage of their labor availability.

Households with access to agricultural extension services are likely to access credit. Agricultural extension services not only improve farming technologies but also provide households with necessary information about credit sources.

The positive coefficient of shock losses indicates that households that experience larger shock losses might choose borrowing as a response to cope with shocks. However, this coefficient is not significant.

The sign of the household location is negative but not significant. The sign of this variable is consistent with the hypothesis that in Soc Son district, economic activities could be more active than those in Lac Son, resulting in better access to microcredit.

The variable describing the distance to the market center aims to capture the transaction costs of accessing market. The positive coefficient sign of this variable reveals that the households in further areas might have a higher probability of accessing microcredit. However, the coefficient is not statistically significant.

In summary, household access to credit is associated with educational level of household heads, land size, family size and access to agricultural extension services.

\subsubsection{Impact of Microcredit on Household Income and Expenditure}

Among welfare indicators, household income and expenditure seem to be the most appropriate indicators (Li et al., 2011; Wetterberg, 2007). Obviously, household outcome is not only influenced by credit access but also by other endowments. The matching technique is, therefore, necessary to infer the casual impact of credit. The significant variables in the probit model serve as the covariates in the second step of the Propensity Score Matching. The propensity scores of both 61 credit accessed households and 116 credit non-accessed households are estimated. The common support option has been selected is [.05888514, .99966743]. Based on the common scores, the final dataset including 28 credit non-accessed households and 61 accessed ones is used to measure the impact. Table 4 reports the welfare impact of credit denoted by the average treatment on treated effect (ATT).

Table 4. Welfare impact of microcredit

\begin{tabular}{|c|c|c|c|c|c|c|c|c|c|}
\hline \multirow{3}{*}{ Welfare } & \multirow{2}{*}{\multicolumn{3}{|c|}{ Unmatched }} & \multicolumn{6}{|c|}{ Matched by PSM } \\
\hline & & & & \multicolumn{3}{|c|}{ Normal matched } & \multicolumn{3}{|c|}{ Bias-corrected } \\
\hline & ATT & $\mathrm{Sd}$ & t-stat & ATT & $\mathrm{Sd}$ & t-stat & ATT & $\mathrm{Sd}$ & t-stat \\
\hline Income & .34 & 2.17 & 0.16 & 2.61 & 4.08 & 0.64 & 4.16 & 2.80 & 0.93 \\
\hline Income per capita & -2.82 & .71 & $-3.99^{* * *}$ & 0.08 & 1.54 & 0.05 & 0.12 & 0.59 & 0.13 \\
\hline Expenditure & 1.09 & 1.88 & 0.57 & 3.02 & 3.49 & 0.87 & 4.26 & 2.74 & 1.10 \\
\hline Expenditure per capita & -2.23 & 0.61 & $-3.67^{* * *}$ & 0.24 & 1.32 & 0.19 & 0.39 & 0.62 & 0.39 \\
\hline
\end{tabular}

Note. ATT: Average Treatment on Treated effect; Bias-corrected by bootstrapping with 1000 replications; ${ }^{* * *}$ Significant at the $1 \%$ level.

Source: Own calculation.

As shown in the table, before matching, accessed households have higher income and expenditure. However, per capita income and expenditure of credit recipients are significantly lower as compared to those of non-recipients. After matching, all welfare indicators of credit accessed households are higher. For example, accessed households obtained 4.16 VND millions of total income, 0.12 VND millions of per capita income 
higher than non-accessed households did. However, all welfare differences are not statistically significant at the $10 \%$ level.

\section{Discussion}

The poor, especially those in disadvantaged areas are able to play a part in creating wealth and improving their livelihood if they begin a small business, improve farming productivity or access employment. The lack of a chance for the poor to become economic independents can lead to the wasteful human capital in the national economic development. Nevertheless, the main disadvantage of the poor is that they lack of access to financial resources to help in archiving their goals. The poor, in general, have a low level of education, limited production skills and limited access to additional resources. Therefore, improving access of the poor to financial services such as microcredit has long been a question of great interest.

This study set out to determine the poverty targeting of microcredit and its contribution in poverty reduction. This study selected the Microfinance Fund and Community Development, a microfinance institution in Northern Vietnam as a case study. To assess the extent to which credit serves the poor, Principal Component Analysis was used to measure the relative poverty indexes, which are less dependent on the purchase power across regions and overtime. The welfare impacts of microcredit on recipients were estimated by calculating average treatment effect on treated through the approach of Propensity Score Matching.

Returning to the research objectives posed at the beginning of the study, it is now possible to state that the microfinance institution has achieved its mission to provide the poor with microcredit services. However, microcredit serves a limited role in improving household income and expenditure. The findings of this investigation complement those of earlier studies. The present study provides additional evidence with respect to the conditions under which credit plays a significant role. Microcredit alone could be not sufficient to poor households, which also demand other complementary services such as risk copping measures access to market and farming technologies. A small amount of loans could be not enough to for farmers to expand production and sustain income. These arguments confirm those by Morduch (1999), Coleman (1999), and (Bauchet \& Morduch, 2013), who revealed that small volumes of credit have no significant impacts on farm profits.

\section{References}

Abdi, H., \& Williams, L. J. (2010). Principal component analysis. Wiley Interdisciplinary Reviews: Computational Statistics, 2(4), 433-459.

Amin, S., Rai, A. S., \& Topa, G. (2003). Does microcredit reach the poor and vulnerable? Evidence from northern Bangladesh. Journal of Development Economics, 70(1), 59-82. http://dx.doi.org/10.1016/S0304-3878(02)00087-1

Austin, P. C., \& Small, D. S. (2014). The use of bootstrapping when using propensity-score matching without replacement: a simulation study. Statistics in Medicine, 33(24), 4306-4319. http://dx.doi.org/10.1002/sim.6276

Bao Duong, P., \& Izumida, Y. (2002). Rural Development Finance in Vietnam: A Microeconometric Analysis of $\begin{array}{lllll}\text { Household Surveys. } & \text { World } & \text { 3evelopment, } & \text { 319-335. }\end{array}$ http://dx.doi.org/10.1016/S0305-750X(01)00112-7

Bauchet, J., \& Morduch, J. (2013). Is Micro too Small? Microcredit vs. SME Finance. World Development, 43(0), 288-297. http://dx.doi.org/10.1016/j.worlddev.2012.10.008

Becketti, S. (1994). Stata Technical Bulletin Reprints (Vol. 3). Stata Corp.

Blundell, R., \& Dias, M. C. (2009). Alternative Approaches to Evaluation in Empirical Microeconomics. Journal of Human Resources, 44(3), 565-640.

Brehanu, A., \& Fufa, B. (2008). Repayment rate of loans from semi-formal financial institutions among small-scale farmers in Ethiopia: Two-limit Tobit analysis. The Journal of Socio-Economics, 37(6), 2221-2230. http://dx.doi.org/10.1016/j.socec.2008.02.003

Buadi, D. K., Anaman, K. A., \& Kwarteng, J. A. (2013). Farmers' perceptions of the quality of extension services provided by non-governmental organisations in two municipalities in the Central Region of Ghana. Agricultural Systems, 120(0), 20-26. http://dx.doi.org/10.1016/j.agsy.2013.05.002

Bun, M. J. G. (2002). A guide to modern econometrics. Economist-Netherlands, 150(3), 320-321.

Caliendo, M., \& Kopeinig, S. (2008). Some practical guidance for the implementation of propensity score matching. Journal of economic surveys, 22(1), 31-72. 
Coleman, B. E. (1999). The impact of group lending in Northeast Thailand. Journal of Development Economics, 60(1), 105-141. http://dx.doi.org/10.1016/S0304-3878(99)00038-3

Coleman, B. E. (2006). Microfinance in Northeast Thailand: Who benefits and how much? World Development, 34(9), 1612-1638. http://dx.doi.org/10.1016/j.worlddev.2006.01.006

Collins, D., Morduch, J., Rutherford, S., \& Ruthven, O. (2009). Portfolios of the poor, How the world's poor live on $\$ 2$ a day.

de Sherbinin, A., VanWey, L. K., McSweeney, K., Aggarwal, R., Barbieri, A., Henry, S., ... Walker, R. (2008). Rural household demographics, livelihoods and the environment. Global Environmental Change, 18(1), 38-53. http://dx.doi.org/10.1016/j.gloenvcha.2007.05.005

Duca, J., \& Whitesell, W. C. (1995). Credit cards and money demand: A cross-sectional study. Journal of Money, Credit, and Banking, 27(2), 604-623.

Dufhues, T., \& Buchenrieder, G. (2005). Outreach of credit institutes and households' access constraints to formal credit in Northern Vietnam.

Filmer, D., \& Pritchett, L. H. (2001). Estimating wealth effects without expenditure data-or tears: An application to educational enrollments in states of india. Demography, 38(1), 115-132.

Foltz, J. D. (2004). Credit market access and profitability in Tunisian agriculture. Agricultural Economics, 30(3), 229-240. http://dx.doi.org/10.1016/j.agecon.2002.12.003

General Statistics Office of Vietnam, G. (2012). The Vietnam Household Living Standards Survey. Hanoi: Statistical Publishing House.

Ghalib, A. K. (2011). Estimating the depth of microfinance programme outreach: Empirical findings from rural Pakistan. SSRN 1895295.

Girish, M., \& Mehta, P. (2003). Crop diversi cation: An empirical analysis on Kangra farms of Himachal Pradesh, India. Asia-Paci fic Journal of Rural Development, 13(2).

Globalagrisk. (2009). Applications of risk assessment and product development in Viet Nam (Vol. 3). Ha Noi: Information Center for Rural and Agricultural Development (Agroinfo), Institute of Policy and Strategy for Agricultural and Rural Development (IPSARD).

Henry, C. (2003). Microfinance poverty assessment tool (Vol. 255). World bank publications.

Hopkins, J., Levin, C., \& Haddad, L. (1994). Women's income and household expenditure patterns: Gender or flow? Evidence from Niger. American Journal of Agricultural Economics, 76(5), 1219-1225.

Huber, M., Lechner, M., \& Wunsch, C. (2013). The performance of estimators based on the propensity score. Journal of Econometrics, 175(1), 1-21. http://dx.doi.org/10.1016/j.jeconom.2012.11.006

Imbens, G. W., \& Rubin, D. B. (2015). Causal Inference in Statistics, Social, and Biomedical Sciences: An Introduction. Cambridge University Press.

Khalid, M. (2003). Access to formal and quasi-formal credit by smallholder farmers and artisanal fishermen: $A$ case of Zanzibar. Mkuki na Nyota Publishers.

Khoi, P. D., Gan, C., Nartea, G. V., \& Cohen, D. A. (2013). Formal and informal rural credit in the Mekong River Delta of Vietnam: Interaction and accessibility. Journal of Asian Economics, 26(0), 1-13. http://dx.doi.org/10.1016/j.asieco.2013.02.003

Kim Anh, N., Van Thu, N., Thanh Tam, L., \& Mai, N. T. T. (2011). Microfinance versus Poverty Reduction in Vietnam-Diagnostic Test and Comparison.

Kornbrot, D. (2005). Point biserial correlation. Wiley StatsRef: Statistics Reference Online.

Li, X., Gan, C., \& Hu, B. (2011). Accessibility to microcredit by Chinese rural households. Journal of Asian Economics, 22(3), 235-246. http://dx.doi.org/10.1016/j.asieco.2011.01.004

MFCD. (2012). Key Statistics. Retrieved April 14, 2014, from http://mfcdi.vn/index.php/our-impact/key-statistics

Milan, F. M. (2012). Social performance of microfinance institutions: Theory and empirical evidence. Hohenheim, Universitaat Hohenheim, Diss., 2011.

Morduch, J. (1999). The role of subsidies in microfinance: evidence from the Grameen Bank. Journal of Development Economics, 60(1), 229-248. http://dx.doi.org/10.1016/S0304-3878(99)00042-5 
Nuryartono, N., Zeller, M., \& Schwarze, S. (2005). Credit Rationing of Farm Households and Agricultural production: Empirical Evidence in the Rural Areas of Central Sulawesi, Indonesia. Paper presented at the Conference on International Agricultural Research for Development Stuttgart-Hohenheim, Germany.

Okten, C., \& Osili, U. O. (2004). Social Networks and Credit Access in Indonesia. World Development, 32(7), 1225-1246. http://dx.doi.org/10.1016/j.worlddev.2004.01.012

Okurut, N. (2004). Credit Demand and Credit Rationing in the Informal Financial Sector in Uganda. Paper presented at the African Development and Poverty Reduction: The Macro-Micro Linkage, Lord Chartes Hotel, Somerset West, South Africa.

Stanton, J. (2002). Wealth and Rural Credit among Farmers in Mexico: Is Market Paprticipation Consistent with Targeting? In M. Zeller \& R. L. Meyer (Eds.), Triangle of Microfinance: Financial Sustainability, Outreach and Impact. London: The John Hopkins University Press Baltimore

Takahashi, K., Higashikata, T., \& Tsukada., K. (2010). The short-term poverty impact of small-scale, collateral free microcredit in Indonesia: A matching estimator approach. The Developing Economics, 48(128-125).

Tam, P. L. T. (2013). The sustainability of Microfinance institutions in Vietnam: Circumstances and implications.

Tektas, D., \& Gunay, S. (2008). A Bayesian Approach to Parameter Estimation in Binary Logit and Probit models. Hacettepe Journal of Mathematics and Statistics, 37(2), 167-176.

Yuan, Y., \& Xu, L. (2015). Are poor able to access the informal credit market? Evidence from rural households in China. China Economic Review, 0. http://dx.doi.org/10.1016/j.chieco.2015.01.003

Zeller, M., Minten, B., \& Lapenu, C. (2000). Socioeconomic situation of rural households and changes in indicators of welfare. In B. Minten \& M. Zeller (Eds.), Beyond Market Liberalization: Income generation, welfare and environmental sustainability in Madagascar. Aldershot, UK: Ashgate.

Zeller, M., \& Sharma, M. (2000). The demand for financial services by the rural poor: International Food Policy Research Institute (IFPRI).

\section{Copyrights}

Copyright for this article is retained by the author(s), with first publication rights granted to the journal.

This is an open-access article distributed under the terms and conditions of the Creative Commons Attribution license (http://creativecommons.org/licenses/by/3.0/). 